Jarosław J. Piątek ${ }^{1}$

\title{
NON-GOVERNMENTAL ORGANIZATIONS IN ENSURING SECURITY
}

Keywords: Security, non-governmental organizations, Third Sector, Information and Communication Technologies

\begin{abstract}
Various social, political and economic contexts give rise to visibly different concepts of security and these differences make one ponder on the limitations of traditional concepts of democratization and political development. Scientists, politicians and activists are now ever more boldly beginning to ask difficult but necessary questions about the appropriate dynamics of the processes of creating security and about the priorities adopted within them, searching for ways on which these processes could be co-created by traditional, local visions of needs of citizens' safe life. The review of scholarly literature and political journalism addressing security points out new spheres of debates and subjects of controversy within this discipline. In a situation where in security-related processes governments cannot be the only ones that dominate, a question about the possibility of expanding activities with non-governmental organizations arises.
\end{abstract}

\section{THE CIVIL SOCIETY - SECURITY RELATIONSHIP}

In contemporary democracies the division into the governing and the governed is obvious; the state stands on the one side, citizens on the other. There are professional politicians and people engaged in politics ad hoc (if at all). In the Western civilization there is a belief that society must be

1 Jarosław J. Piątek, University of Szczecin, PhD student - third year doctoral student at the Institute of Political Science and Security of the University of Szczecin, jarekpiatek@ wp.pl. ORCID ID: 0000-0003-4754-3371. 
included in the operation of the mechanisms of politics (Tansey, 1997, p. 178). Contemporary times interpreted by security aspects are no longer dominated by interstate conflicts, regional threats, ever more innovative and dangerous terrorist strategies, new problems arising from the dynamics of globalisation; there are also challenges which are a resultant of religious and ideological extremism. Our surroundings are filled with a policy of anger triggered by indecent disproportions of wealth and opportunities and all perturbations causes by the fierceness of global environmental changes. Intensive and multidimensional insecurity affects the understanding of contemporary times and predictable future, and each of us pursuing security. Despite the fact that the state is a basic legal form of organizing the society and decisions on security are taken mainly on the state level, on the micro scale, i.e. individual, is it the people who are the most important advisory, decision-making and competent organs in terms of acting for minimizing threats. In a democratic system, it is the citizens who play the role of a messenger, an in-between, whose task is to i.a. coordinate the activity of the state with the private and social sector (Jakubczak-Krawczyńska, 2017, pp. 102-103). The effectiveness of operation of a democratic system, though conditioned on a number of factors independent of each other, increases when the state environment features developed social bonds, extended communities and high social activity of citizens.

The purposefulness of the undertaken actions in terms of creating the policy of security without the society is doubtful.

The dynamics of changes, the level of society's engagement as part of such activity is outlined only by state citizens who are active, aware of their capabilities and educated, therefore a significant task that rests on each modern state democracy involves adequate management of resources within the framework of the discussed environment (Sasinowski, 2012, pp. 41-42). Thanks to a developed civil society, the potential of state's social development is enhanced, and so is the promptness of responses and of carrying out entrusted tasks, as well as, which is important from the point of view of security, the ability to respond to external threats. Despite this, citizens' activity in the sphere of social pursuits may also initiate an objection against the existing state system, an undesirable state 
of facts and disagreements, which is often an impulse for creating rebellious movements (Jakubczak-Krawczyńska, 2017, p. 103). Thus, the entity's activity determines the quality of functioning, the speed of development and directions of development of civic activity, it is the citizen as a stakeholder that is the most important element of the system of civil society in each country. Regardless of the adopted stand, civil society as a merged part of state democracy, should be an equal partner for the other areas of state activity in terms of both the security and the functioning of the entire state environment.

The concept of "civil society" is not unambiguous and occurs on many planes, depending of the discussed main theme. In order to understand the essence of contemporary security, citizens' activity within the community is one of the main pillars of operation and one of the determinants of the quality of security in the human security approach. The term civil society is often described in literature, where certain common features of this concept have been formed as part of the developed definitions. D. Moroń in her work Organizacje pozarzadowe - fundament społeczeństwa obywatelskiego [Non-governmental organizations - foundation of civil society] attempts to synthesize contemporary definitions of this concept (Moron, 2012, pp. 47-51). In her approach, civil society needs to be understood as a certain autonomous area of civil activity, a certain space in which citizens voluntarily affiliated under institutions, social organizations and other communities, undertake collaboration in order to achieve the adopted intentions and to realize common interests for the benefit of the general good. A similar visualisation of this concept is presented in the Strategy for Supporting the Development of Civil Society for 2007-2013 drawn up by the Ministry of Social Policy, where it is emphasized that it is an area which extends between the state sector, the family and the market, thus the private sector (Strategia Wspierania Rozwoju...). Thus, also within the third sector of social and economic activity, that is associations, foundations, voluntary work, etc. its manifestations need to be observed (Szacka, 2003, p. 410). The idea of their activity was based on: voluntary social activity, complete independence, readiness to cooperate within common interests and activity in the sphere between the public and private sector. The essence of the operation of civil society is citizens- 
controlled cooperation of local communities with state and private institutions, in order to achieve the set goal. Regardless of the applicable system or the model or relations between these entities, one of the main factors triggering the activity of civil society is the pursuit to ensure one's own security, removal of or minimizing threats to survival and improvement of the system's organization which is to ensure this security. The prime aim of each entity in itself, apart from ensuring direct physical security, is also limitation of welfare and social threats, that is those associated with direct survival, protection of life in the existential dimension and implementation of basic aims associated with aspirations and basic needs of self-actualization. It is strictly related to each man's natural drive to survive in the worst conditions. Despite this, one may observe here the hierarchy nature of security-related needs and individual pursuits of securing each activity to the greatest possible degree. This results from an innate need of security and people's pursuit to create communities.

\section{THIRD SECTOR OF ACTIVITY FOR SECURITY IN POLAND}

The term "non-governmental organizations" has become established in our realities. In the Polish language there are also other terms, used interchangeably, such as social organizations or civil organizations. The English language also has a number of terms such as voluntary organizations, non-profit organizations and the above-mentioned civil organizations. When talking about non-governmental organizations, one needs to set off from a broader term used in Poland which is also a translation of an English phrase that began to be used world-wide at the beginning of the 1970 s. It is the term "third sector", which denotes all forms of social activity located between the state (first sector) and the market (second sector). Non-governmental organizations also fall within it. The third sector includes various forms of affiliations, artificially created target groups (associations) as differentiated from communities, that is natural relationships, such as family. The concept of a non-governmental organization is often used in the literature. Regardless of the subject or aims of presenting 
this notion, the definition is unequivocal and the possible differences do not affect its perception to a greater degree. In Poland the concept of a non-governmental organization was first legally placed in the act of 24 April 2003 on public benefit activity and volunteering. Pursuant to Article 3 of the said act: "Non-governmental organizations are 1) entities which do not form part of the public finance sector as defined in the Act on Public Finance; 2) which do not operate for profit - corporate and noncorporate entities, which according to separate legal provisions have capacity to perform acts in law, such as foundations and associations ..." (Article 3(2)). Despite this, it needs to be remembered that a number of organizations fulfilling the role of non-governmental organizations operate on the basis of provisions that precede the creation of the 2003 Act. Examples of such organizations include: the Polish Hunting Association (Polski Związek...) and the Polish Red Cross (Polski Czerwony...) which function on the basis of various acts (Arczewska, 2007, p. 6). The act, however, only specifies the main principles of cooperation at the same time outlining the obligation to undertake cooperation programmes with local government units, which from the point of view of local security is incredibly important. Moreover, it regulates the matters associated with the possibility of cooperation with public administration as well as local government and private actors.

In Poland, a majority of organizations established on public initiative take part in shaping the security of local environment, closest to an individual. Those with the greatest representation in our country are voluntary rescue organizations or organizations with a health-, ecology- or culturerelated profile.

A significant share of them actively participate in operations which are part of a crisis management system in which the social element is its fundamental part.

Organizations acting within this scope may be classified into four groups according to the universality and comprehensibility of readiness to be employed in crisis situations (Drabik, 2015, p.155-156). The first is created by Voluntary Fire Brigades affiliated with the Association of Voluntary Fire Brigades of the Republic of Poland, which is an association functioning on the basis of the act of 7 April 1989 - Law on associations 
and the act of 24 August 1991 on fire protection. Legal placing of Voluntary Fire Brigades has incorporated most of them into the National Firefighting and Rescue System (KSRG) which allows coordination of these entities i.a. with the State Fire Service and other KSRG units (Organizacja KSRG_2019...). This group includes non-governmental organizations of a rescue nature, which due to legal and statutory obligations deal with providing help to persons in sudden health threats (Article 15 section 9). Such organizations include: the Mountain Volunteer Search and Rescue (GOPR), the Tatra Volunteer Search and Rescue (TOPR), the Water Volunteer Search and Rescue (WOPR) and other units whose tasks are of similar nature. All enumerated entities operate on the basis of separate legal acts. GOPR and TOPR operate on the basis of the act of 18 August 2011 on safety and search and rescue in the mountains and on organized skiing areas (Dz. U. (Journal of Laws) of 2011 item 1241 as amended). WOPR is legally situated in the act of 18 August 2011 on the safety of persons in water areas (Dz. U. (Journal of Laws) of 2011 no. 208 item 1240 as amended) (Trocha, 2014, p. 111). The next group is composed of entities of a social and educational nature, that is all those whose activity is based on an educational and upbringing model of society. They include all sporting, cultural and educational associations and also those created by religious communities. An example of such organizations includes shooting associations and shooting federations. The last group affiliates entities of a unique, often very broad access to resources and means, to which public authorities and state institutions have limited access. These include e.g. aero clubs, charities and associations affiliating owners of facilities or objects which e.g. may serve to fill the material gap during a crisis. Unique entities of a special public benefit nature may also include paramilitary organizations which encompass the above-mentioned shooting federations, associations of sport shooting instructors, gymnastics federations and also individual associations of the Academic Legion (Soloch, Żurawski vel Grajewski, Dryblak, 2015, p. 26).

There is no doubt that third sector organizations, due to their human and equipment potential, should be used in terms of supporting the state in ensuring order within the country and in terms of strengthening institutions and services that carry out tasks for citizens' internal security. 
However, the scope of their use and especially implementation of tasks must be adopted to the changing requirements and emerging threats (Hudzikowski, Zapałowski, 2014, pp. 9-48). Natural disasters of the past years on the territory of our country have proved the state's insufficient preparedness to carry out effective rescue operations. Public services, in the opinion of specialists, were not able to get mobilized for the fight against the element (Ciszewski, 2011, p. 381). Contemporary threats have a comprehensive nature and outcomes of crises place the entire society at risk. Society in the broadest possible dimension should be prepared to counteract them. Given the absence of effective instruments of forecasting disasters, quick mobilization for a fight against threats may limit losses in people and property. These measures are a test of their real work (Morawski, 2014, p. 47). An important factor involves cooperation with a nonmilitary system which contributes to the efficiency of operation of all forces engaged in crisis management on the territory of the country. Third sector actors are an exceptionally flexible and mobile resource of social and economic benefit and a number of them, for the time of a crisis situation, as part of crisis management, are able to transform their profile and adjust the nature of activity to the resulting unusual circumstances.

\section{THE ACTIVITY OF “PREPPERS" AS AN EXAMPLE OF CITIZENS’ ACTIVITY FOR THE SAFETY OF THE INDIVIDUAL}

There are threats throughout the world for which we cannot get fully prepared. States and their institutional security systems regularly redefine security and reorient their actions in terms of minimising and combating threats. This is naturally associated with the emergence of ever new hazards in various areas. This does not change the fact that the resource of forces and means as well as tools that the state has at its disposal in order to be able to act in this regard is limited. Despite being aware of the existence of threats that may be caused by i.a. natural disasters, nuclear wars, epidemics and other similar incidents, citizens often are not aware of the results they entail. Crisis situations, emerged as a result of long-term pres- 
ence of said events may, on a global scale, prove impossible to manage, which in consequence may result in irreversible changes for the ecological environment, for the society, public life and regular day-to-day life of each of us. For many people this may seem a simply abstract thing, an impossible scenario, and yet there are organized groups of people in the world which live in such a way as to be prepared for the coming of the worst possible circumstances.

In the 1950s, in the USA, one of the more real threats which had an impact on the citizens of the United States was the threat of an outbreak of an atomic war. The then Soviet Union and the USA, who were gradually developing a technology of transportation systems for nuclear loads, caused the citizens to believe that the increasing conflicts could result in an outbreak of a war before which there was no hiding. This is how first groups of preppers were born on the foundation of survivalists movements (Drozdowicz, 2012, p. 82). The name of this specific movement derives from the English words prepping or prepared. This term is sometimes associated with the aforementioned survivalists movement as well as with survival itself, yet one may notice fundamental differences between these two notions. As much as survival concerns mainly sudden crisis situations in which an individual strives to survive and thus to combat this situation, in the case of preppers, the element of survival is a result of action as part of preparation for extreme irreversible situations (prepping, survival, bushcraft). Even though the term itself is not officially defined in the Polish law, preppers' activity is a concept which has been anchored so far only in groups coming from specific thematic niches, today they may be defined in a much broader scope.

Currently, a prepper may mean any person who prepares for not only a situation of an existential importance, but also for any long-term but prosaic crisis situation in which they predict that they may find themselves in the future. In other words, one may call so a person who gathers supplies for winter, builds solar electric installations in their homes, buys tools and clothing or stores long-life food. Sometimes without being aware of that we become preppers despite the fact that our intentions do not overlap actual pursuits of "the prepared". Thus, modern prepping may manifest itself in a much broader scope of activities. However, tradition- 
ally, everyone who prepares for the "end of the world" which may happen as a result of extreme sudden events is a prepper. These events include i.a. terrorist attacks, natural disasters and cataclysms, wars and arms races (likelihood of a nuclear war), states' economic downturns and collapses or cyberspace attacks and also everything that may come up after the emergence of such situations, that is anarchy, fall of governments, uncontrolled migrations, etc. (Kim jest prepper?). Regardless of the degree of preparedness, a prepper's aim is to get ready for scenarios that are possible to predict and implement. Even though the preppers' movement originated in the USA, a noticeable, organized group of people which falls under such activity has already appeared in Poland. The biggest nongovernmental organization of a preppers' theme is the Polish Preppers Network whose creator is Piotr Czuryłło, one of the most active Polish preppers. The foundation's objects involve exchange of information and coordination of activity between various groups of the Prepared, exchange of experiences and organization of events and conventions that are helpful in such activities. When it comes to literature, at the moment there are not many positions referring to this concept (Chełchowski, Czuba, 2017), which does not seem an obstacle for a small but constantly growing community of preppers. This community is present in the social media and on YouTube, where numerous materials addressing this issue are published regularly.

The prepared's attitudes and activities have a pro-defence nature. The drive to survive sometimes shapes their individual, minimalist lifestyle and the strive for independence. Despite this, organized groups of preppers support each other eagerly, organize trips and training sessions. Preppers are guided in their life with the principle of utilitarianism, that is an approach to perceive various skills and tools from the point of view of their usefulness. They learn survival skills, close combat, handling cold or fire arms. Moreover, they engage in gathering appropriate food supplies and objects necessary to survive, often modifying their place of residence so that it can provide self-sufficient shelter for a long time (Zych, 2017, p. 294). Such activity is, however, practised for other purposes such as loss of a job or of family property, the death of a breadwinner, treats resulting from living in flood areas or areas at risk of drought or other extreme 
weather phenomena. A prepper's task is to be prepared for anything. Despite the fact that in the opinion of some such behaviours may seem completely unnecessary, or even insane, the attitudes created by the prepared are incredibly useful from the point of view of the functioning of the state and society. Preppers' activity may significantly affect the perception of security and its actual state (in an adequate scale) in extreme situations when state forces and measures deployed to combat a crisis situation fail. The immediate readiness to act and care for the closest local environment may significantly limit the effects of the occurrence of given threats. This is associated with preppers far-reaching activity in terms of education, logistics and organization of pro-defence actions. Such activities include: training sessions and practical courses based on the principles of simulation of crisis situations; improving the quality of the shelter's equipment and expansion of its defence-related elements; improving alarm systems, evacuation systems and the possibility to transmit data by means of technical devices, but also all activity enhancing the related decisionmaking and information possibilities. From the point of view of an individual, such preventive action is aimed at protection of values which are closest to us, that is family home and immediate family as well as health, life and property. Moreover, they are based on the basic survival technique and propagate utilitarian, economic behaviours in order to minimize threats resulting from the need to survive.

The preppers movement is a reflection of a strong need to survive in a hostile environment, in an individual micro scale which results from the dominant role of the prime instinct orientated at living through. Even though in Poland such activity is not popular enough for wider circles to engage in them structurally, it undoubtedly provides positive emphasis of civil activity in terms of acting for one's own security. 


\section{EXPANDING THE ORGANIZATION'S AREA OF OPERATION. SOCIAL IMPACT OF ICT (INFORMATION AND COMMUNICATION TECHNOLOGIES)}

A new wave of technology is driving rapid global changes. The "waves" of technological changes, driven by inventions - from steam power to electricity for cars - inspire economic progress and social transformation in the most recent history (Sachs, 2015, p. 82). Many talk about "technological revolutions": the first industrial revolution which mechanised production, the second, which led to mass production, and third - automated production. It has been argued that we are now in the phase of a fourth industrial revolution in which the fusion of various technologies blurs the boundaries between the physical, digital and biological sphere (Yáñez, 2017; Latiff, 2018, pp. 43-44). Compared with previous industrial revolutions, the fourth revolution proceeds at an exponential, not a linear pace. What is more, it distorts almost all industry branches in each country and the breadth and depth of these changes herald a transformation of entire systems of production, management and supervision. It seems that the expansion of new technologies, ranging from the Internet to synthetic biology technologies, cannot be stopped. Technological changes have created new possibilities of multilateral cooperation in the areas that have been under-appreciated and marginalised, because they create new determinants in managing relations between the state and society, and between states. New technologies and platforms to an increasing extent allow citizens today to get involved in governance, expressing one's opinions, coordinating efforts for the quality of knowledge, or even exercising public authority supervision (Anti-Counterfeiting Trade Agreement ACTA).

The potential of new technologies, in particular information and communication technologies (ICT) is invaluable. Even though there is no single universal definition of information and communication technologies, this term is generally accepted to mean all devices, network components, applications and systems which jointly allow people and organizations (i.e. companies, non-profit organizations, governments or criminal organizations) to interact with the digital world. The list of ICT 
components is exhaustive and is constantly growing. Some elements, such as computers and telephones, have been around for decades. Others, such as smartphones, digital televisions and robots, are newer creations. ICT also includes the sphere of Internet access and the mobile sphere powered with wireless networks. It also includes old-fashioned technologies, such as land line phones, the radio and TV transmissions, of which all are still widely used today, next to the newest ICT elements such as artificial intelligence and robotics.

Information and communication technologies are a basis of wide changes in society, because mass units move away from personal face-toface interactions to interactions in the digital sphere. This new age is often called the Digital Age.

However, access to ICT remains highly unbalanced in developed and developing countries, wealthy or poor. While 82 percent of people in developed countries use the Internet, on the global scale this percentage is only 43, 35 percent in developing countries, 11 percent in Africa and 9 percent in least-developed countries. The distribution of access to cell phones looks slightly better, though the prices of related services remain the highest in the poorest countries. Without high quality data that provides information on security it is already impossible today to design, monitor and assess effective security policies. Ultimately, technologies allow a better understanding of the assessed phenomenon, make it easier for decision-makers to track the development of the situation and give basis for remedial action. Programmes that are already acting for security by implementing information and communication technologies allow minimizing the risk associated with natural disasters such as a tsunami. Mobile phones and social media also provide opportunities to strengthen efforts to minimize threats created by military conflicts. Photos and videos uploaded to social media in real time often become a proof to the scope and quality of violence (Larrauri, Kahl, 2013, p. 3). As a result, they may accelerate the government(s) response to other sources of conflicts. These technologies have also revolutionised peoples' ability to organize and coordinate protesting movements, from the Arab Spring to the war in Ukraine. This may have both positive and negative consequences. One needs to remember that technologies equally often cause an increase of 
invigilation and restriction of personal rights, while easy manipulation of information and sources as well as the risk of their viral dissemination without verification may promote disinformation. Social media users risk finding themselves in "information cocoons" where they do not come across different opinions, which potentially increases political polarization (Nagel, 2001, pp. 31-34.). On the other hand, social media may also facilitate blocking and combating radical ideologies. Platforms such as Facebook may be used to increase positive interaction between people, often hostile towards one another due to competitive political programmes, ideologies or ethnic or religious identity. Groups such as Peace Factory use Facebook to connect people in Israel with people in Iran, Palestine or Jordan, and groups such as Umati in Kenya or Proxi in Spain use social media to monitor and counteract hatred. In Sudan, where the government used technology to limit access to the Internet, a local nongovernmental organization established a system of social connectivity which connects a text message with the radio in order to help maintain local agreements for normalization of life and enhancing security. Video games teach war, but Games for Peace use Minecraft to gather young people of Israel and Palestine (Larrauri, Kahl, 2013, p. 6).

\section{CONCLUSIONS}

The formula of civil society, regardless of the differentiated scholarly and commentary context of the analysis and explanations of its essence, includes universal principles and values without which any attempt to create its real basis and conditions for development is doomed to fail. In a democratic system, at the level of an individual, a social group, a local community or a global society, fundamental principles and values that affect social attitudes and behaviours, manifestations of various forms of civil activity, including non-governmental organizations, gain particular importance for security. They include most of all: freedom and responsibility, sovereignty and partnership, auxiliary nature and participation or human solidarity. 


\section{BIBLIOGRAPHY:}

Arczewska, M. (2007). Nie tylko jedna ustawa. Prawo o organizacjach pozarzadowych, Warsaw: Instytut Spraw Publicznych.

Article 15 section 9 of the act of 8 September 2006 on National Emergency Medical Services, (Dz.U. (Journal of Laws) no. 191 item 1410).

Article 3 section 2 of the act of 24 April 2003 on public benefit activity and volunteering, (Dz. U. (Journal of Laws) of 2010 no. 234 item 1536 as amended).

Chełchowski, W., Czuba, A. (2017). Preppersi. Przygotowani do przetrwania!! Warszawa: MUZA S.A.

Ciszewski, Tomasz (2011), Udział sił zbrojnych Rzeczypospolitej w zapobieganiu oraz usuwaniu skutków zagrożeń niemilitarnych. Zeszyty naukowe WSOWL, no. 2, pp. 363-383.

Drabik, I. (2015). Rola i znaczenie organizacji pozarządowych w zarządzaniu kryzysowym. Zeszyty Naukowe Politechniki Częstochowskiej, no. 20, pp. 149-162.

Drozdowicz, J. (2012). Preppersi, EDC i nowy millenaryzm. Przeglad Religioznawczy, no. 1, pp. 81-90.

Jakubczak-Krawczyńska, K. (2017). Organizacje pozarządowe w zapewnianiu bezpieczeństwa państwa demokratycznego. In: B. Pacek, T. Szmidtka, K. JakubczakKrawczyńska (ed). Organizacje pozarzadowe w zapewnieniu bezpieczeństwa państwa (pp. 101-114). Piotrków Trybunalski: Wydawnictwo UJK.

Kim jest prepper?. [Access: 27.02.2020]. Downloaded from: http://preppersi.blogspot. com/2012/11/kim-jest-preppers-prepper-jest-osoba.html

Larrauri, Puig H., Kahl, A. (2013). Technology for Peacebuilding. Stability: International Journal of Security \& Development, no. 3, pp. 1-15.

Latiff, H. R. (2018). Przyszła wojna. W obliczu nowego globalnego pola walki. Warszawa: Wydawnictwo Naukowe PWN.

Morawski, Antoni (2014), Wykorzystanie potencjału organizacji pozarządowych w procesie zarzadzania kryzysowego, Warsaw: Wydawnictwo Uniwersytet Warszawski

Moroń, D. (2012). Organizacje pozarządowe - fundament społeczeństwa obywatelskiego. Wrocław: Wydawnictwo Uniwersytetu Wrocławskiego.

Nagel, T. (2002). Concealment and exposure: and other essays. New York: Oxford University Press.

Organizacja KSRG_2019. Komenda Główna Państwowej Straży Pożarnej. [Access: 07.05.2020]. Downloaded from: https://www.straz.gov.pl/panstwowa_straz_pozarna/ krajowy_system_ratowniczo_gasniczy

Dz. U., 1964, No. 41 item 276 as amended.

Dz. U., 1995, No. 147 item 713 as amended. 
Prepping, survival, bushcraft - co jest czym?. [Access: 27.02.2020]. Downloaded from: https://prepperspodcast.pl/prepping-survival-bushcraft/

Sachs, D. J. (2015). The Age of Sustainable Development. New York: Columbia University Press.

Sasinowski, H. (2012). Społeczeństwo obywatelskie i jego rola w budowie demokracji. Economy and Management, no. 1, pp. 30-47.

Soloch, P., Żurawski Vel Grajewski, P., Dryblak, Ł. (2015). Organizacje proobronne w systemie bezpieczeństwa państwa. Charakterystyki wybranych armii państw europejskich na tle armii polskiej Raport.Warszawa: Instytut Sobieskiego.

Strategia Wspierania Rozwoju Polityki Społecznej na lata 2007-2013, Ministerstwo Polityki Społecznej, Warsaw 2005, p. 7. . [Access: 10.02.2020]. Downloaded from: http:// www.europedirect-katowice.pl/ed_stara_strona/dokumenty/2/strategia-rozwojuspoleczenstwa-obywatelskiego.pdf

Szacka, B. (2003). Wprowadzenie do socjologii. Warszawa: Oficyna Naukowa.

Trocha, J. (2014). Działalność organizacji pozarządowych na rzecz systemu zarządzania kryzysowego Rzeczypospolitej Polskiej. Obronność. Zeszyty Naukowe, vol. 4, no. 12, pp. 105-116.

Yáñez, F. (2017). The Goal is Industry 4.0: Technologies and Trends of the Fourth Industrial Revolution, independently published

Zapałowski, A. (2014). Rola Sił Zbrojnych RP w zapewnieniu bezpieczeństwa wewnętrznego. Hudzikowski M., Zapalowski A. (ed.), Studia wschodnie: polityka gospodarka - bezpieczeństwo, Częstochowa: Instytut Geopolityki

Zych, Jan (2017) Udział preppersów w kreowaniu postaw proobronnych, in: Organizacje pozarządowe w zapewnieniu bezpieczeństwa państwa. In: B. Pacek, T. Szmidtka, K. Jakubczak-Krawczyńska (ed). Organizacje pozarządowe w zapewnieniu bezpieczeństwa państwa (pp. 291-300). Piotrków Trybunalski: Wydawnictwo UJK. 